\title{
Observations on two very large Bacteria, Caryophanon latum Peshkoff and Lineola longa (nomen provisorium)
}

\author{
By E. G. PRINGSHEIM and C. F. ROBINOW \\ Botany School, University of Cambridge and Strangeways \\ Research Laboratory, Cambridge
}

SUMMARY: The organism Caryophanon latum Peshkoff, a very large, Gramnegative, peritrichously flagellated bacterium of unusual structural complexity, which Peshkoff (1940) found in cow dung near Moscow, has been isolated in pure culture from Cambridgeshire cow dung.

The organism grows only poorly on routine nutrient agar, but thrives on yeastextract + meat-extract agar, especially if supplemented with small amounts of sodium acetate. In liquid media it does not multiply, but very siıall concentrations of agar are sufficient to enable it to grow.

Individual cells of $C$. latum have a diameter of $2 \cdot 5-3 \cdot 2 \mu$. and are $10-30 \mu$. long or longer. They divide by binary fission like ordinary bacteria but have in reality a chambered, many-celled structure which gives the organisms a superficial resemblance to filamentous Cyanophyceae. The cell units are either discoid or shortly cylindrical and contain configurations of Feulgen-positive chromatinic bodies, similar to, but more complex than, those found in ordinary bacteria. We regard them as nuclear structures.

The provisional name of Lineola longa is proposed for another very large, Gramnegative, filamentous bacterium of unusual morphology, very different from Caryophanon latum, also found in cow dung. The new organism is peritrichously flagellated and grows in filaments, $1 \cdot 5 \mu$. wide and up to $200 \mu$. long. The component cells of the filaments are few in number and exceedingly long, often 20-50 $\mu$. Fragmentation into smaller units, which is the usual fate of filamentous forms in ageing cultures of ordinary bacteria, was never observed in $L$. longa.

In 1940 Peshkoff described Caryophanon latum, a new, very large bacterium distinguished by a high degree of structural differentiation.

Peshkoff first found this extraordinary non-sporing, Gram-negative bacterium in fresh cow dung gathered in the neighbourhood of Moscow. Pure cultures were obtained by plating samples which had been diluted with 2-3 parts of water and allowed to stand for $15-20 \mathrm{hr}$. From the study of living material Peshkoff concluded that the long rod forms, which represent the natural growth habit of the new organism, 'are not divided into separate cells and represent closed tubes containing a varying number of nuclei and a common protoplasm'. In 1946 he elaborated his point of view further and published high-power photographs of living C. latum filaments.

We have repeated Peshkoff's observation on the occurrence of $C$. latum in dung and have isolated and reinvestigated the organism. During this work a second very large but otherwise very different Gram-negative bacterium, previously undescribed, was encountered. The investigation of the two microbes revealed that the variety of organization possible in bacteria is larger than is commonly assumed. 


\section{CARYOPHANON LATUM PESHKOFF}

Habitat. The immediate success of our search for Caryophanon latum suggests a wide, perhaps ubiquitous, distribution of this organism in fresh cow dung. The failure of earlier investigators to discover such a large, common and actively motile organism may be attributed to the fact that old manure, so often investigated on account of its practical importance, does not contain C. latum.

Under ordinary conditions $C$. latum reaches the peak of its development in cow dung a day or two after the faeces have been dropped in the field. The organism also appeared in two out of four samples collected during the winter from the surface of very fresh cow droppings on clean straw in a well-kept byre where gross contamination from the soil could be ruled out. On the other hand, the organism failed to develop in any of four samples of the contents of the rectum of cows, collected at the slaughterhouse. Thus we have not been able to decide whether $C$. latum is present in the intestines of cattle, or whether it is a strictly saprophytic organism which finds in cow dung particularly favourable conditions for its multiplication.

Isolation. Peshkoff found C. latum in three out of seven samples of cow dung. He does not state whether the dung was collected in field or cow-shed. We looked for the organism in cow droppings from grass land in Cambridge and had no difficulty in finding it, without dilution or special preparation of the dung, in five out of seven samples collected at the end of August 1945. In the next two months fourteen more samples from different localities were examined and nine of these were also rich in this species. In the following spring cow droppings collected in yet another place were again found to contain large numbers of the organism. Some samples contained smaller numbers than others, but since the period of development of the bacillus in dung is short, the number of motile organisms of characteristic appearance thereafter rapidly falling to zero, the best time for inspection may sometimes have been missed. Few or none of the large bacteria were found in samples of very fresh droppings, but the number usually increased greatly when the material was kept in its own moisture in closed glass jars at room temperature for a day or two. After this interval single loops-full of dung suspended in water were teeming with thousands of the actively motile rod form (Pl. 1, fig. 1).

To obtain a pure strain, a drop of a suspension of dung rich in C. latum was streaked on dung agar. Colonies of the large bacterium were visible, among those of other organisms, after $24 \mathrm{hr}$. In spite of their small size, it was not difficult to pick up individual colonies with a capillary pipette, and by repeated plating to obtain pure cultures. Other pure strains were obtained with greater ease by plating suspensions in which $C$. latum had been concentrated by fractional low-speed centrifugation. Five strains obtained in this way and on which the following description is based, were identified as C. latum Peshkoff. C. tenue Peshkoff (1940), a somewhat smaller organism, was never encountered in our material.

Cultivation. The dung agar used by Peshkoff was not a very satisfactory culture medium in our hands. Different dung samples varied greatly in growth- 
promoting power, and even when growth was good the bacteria were abnormally short, coiled and varied greatly in size. The addition of peptone, beef-extract or glucose and alterations of the $\mathrm{pH}$ proved to be either unfavourable to growth or without effect. On slightly alkaline nutrient agar (containing $0.5 \%$ Bacto peptone and $0.5 \%$ Bacto beef-extract) growth was much the same as on dung agar. This was contrary to the experience of Peshkoff, who found that $C$. latum did not grow on ordinary culture media. Very good growth was obtained on yeast-extract agar. Some batches of laboratory-made autolysates of baker's yeast gave excellent results, but others were unsatisfactory, and eventually we relied on the Difco product (Difco Laboratories Inc., Detroit, Michigan) in combination with either Bacto peptone (Difco) or Bacto beef-extract (Difco). Small amounts of sodium acetate had a specific growth-promoting effect in yeast-extract + beef-extract or yeast-extract + peptone media, giving heavier and more uniform growth than with any other combination of ordinary nutrients examined. A medium containing $0.50 \%$ Bacto yeast-extract, $0.50 \%$ Bacto peptone and $0.01 \%$ sodium acetate, adjusted to $\mathrm{pH} 7 \cdot 4-7 \cdot 6$, proved very favourable for isolation and maintenance.

In our cultures $C$. latum, which originally had a diameter of about $3 \mu$., has become somewhat smaller since its isolation some 8-12 months ago and now rarely exceeds $2 \cdot 5 \mu$. in diameter. Migula (1897) reported the same experience with the originally very large Bacillus oxalaticus.

Grozth on agar media. In $18 \mathrm{hr}$. at $26^{\circ}$, on the yeast-extract peptone acetate medium $C$. latum forms colourless, convex, circular, undulate colonies with an undulating edge, rarely exceeding 1-2 $\mathrm{mm}$. in diameter, with a smooth or finely granular glistening surface. It grows in two forms of colony, exhibiting some of the characters of a rough or a smooth growth habit. Both may appear on first isolation. The smooth form predominates, but after some months in culture strains originally fully smooth may give rise to rough colonies, a phenomenon already noted by Peshkoff (1940). The smooth colonies consist of closely packed rods of fairly uniform length and have at first rather angular, jagged outlines (Pl. 1, fig. 2), but later become round or polygonal with smooth, unbroken contours. The rough colonies consist of long, loosely arranged and much folded chains which give a wavy, irregular outline to the colonies. The differences between smooth and rough colonies are more pronounced in young than in old cultures because after several days of growth the chains in the rough colonies break into short bacillary forms.

At the height of its development in cow dung the organism is a cylindrical, often slightly tapering, straight or gently curved rod, 10-30 $\mu$. long and about $3 \mu$. wide, with rounded ends. The same dimensions are attained by $C$. latum in the periphery of young colonies on suitable media. Old cultures consist mainly of very short rods and single, more or less spherical cells (Pl. 4, figs. 11-13). In some samples of cow dung the rods were arranged end to end in chains of $200 \mu$. and longer.

The bacterium grows well at all temperatures from 20 to $37^{\circ}$; most of the observations described in this paper were made on cultures incubated for $18 \mathrm{hr}$. at $26^{\circ}$.

Colonies of recently isolated strains, after several days of growth on 
apparently favourable media, are liable to undergo a peculiar process of disintegration and are transformed into translucent patches consisting chiefly of empty cell walls and granular debris. The lysis first occurs in areas of confluent growth, and well-isolated colonies usually remain unaffected. Among the debris of lysed bacteria, structures resembling those in organisms of the pleuropneumonia group (the $\boldsymbol{L}$-organisms of Klieneberger (Klieneberger \& Smiles, 1942)) are very conspicuous. Small numbers of these elements, crisply staining vesicles with peripheral granules, were present after less than $24 \mathrm{hr}$. incubation in the colonies of all freshly isolated strains that we examined. It is still uncertain whether they represent a growth form of the bacterium or indicate the presence of a symbiont or parasite.

Growth in fluid media. According to Peshkoff, C. latum does not grow well in liquid media; this has also been our experience. Growth in dung extract was scanty, restricted to the surface and composed of deformed cells. Changing the $\mathrm{pH}$ of the extract and the addition of meat extract, peptone and glucose caused no improvement. Surprisingly enough the addition of very small amounts of agar (e.g. $0 \cdot 1-0 \cdot 2 \%$ ) to these liquid media stimulated growth considerably, although the cells were still abnormal in comparison with those grown on solid agar.

General morphology. C. latum is actively motile. Flagella stains and electron micrographs reveal a dense coat of peritrichous flagella whose diameter is approximately the same as that of the flagella of Proteus vulgaris and whose length is $9-12 \mu$. (i.e. three to four times the width of the organism). Curved individuals may convey the impression of a writhing, snake-like movement, but the organism is quite rigid and incapable of active change of shape. In agar cultures the bacterium often swims actively in the thin film of moisture covering and surrounding young colonies. It also slides quickly to and fro, at the same time rotating rapidly on its long axis where the wire loop has made shallow grooves in the surface of the medium. Prevented from moving about, e.g. by the pressure of a cover-glass placed on colonies growing on agar, many individuals, while remaining stationary, spin rapidly on their axes. These observations suggest that this bacterium would be a rewarding subject for a study of flagellar movement.

Apart from their large size and lively motility, the most conspicuous feature of the living organisms is a pattern of more or less regularly spaced, parallel, transverse lines which divide the long rods into a series of discoid compartments (Pl. 1, fig. 3). In optical sections of the bacteria, the transverse lines appeardark and the contents of the compartments bright. In organisms from young cultures continuous transverse lines are frequently found alternating with others that are interrupted by a central gap. Here and there particularly refractive compartments are seen, compressed into a biconcave shape by the adjoining normal ones (Pl. 1, fig. 3); their incidence increases greatly with the age of the cultures.

Peshkoff $(1940,1946)$ maintains that the clear sections of the filaments are nuclei (hence the derivation of the generic name), and that the lines between them represent the cytoplasm. It seemed more plausible to us to regard the relatively dark, parallel, transverse lines as cell boundaries, the clear sections between them as cytoplasm plus nuclear structures, and the biconcave, 
particularly refractile sections (not mentioned in Peshkoff's description) as dead compartments, compressed by the turgor of the adjoining cells. A study of fixed and stained preparations has confirmed our ideas.

\section{The detailed structure of Caryophanon latum}

Methods of fixation. The bacteria were fixed wet and while still on the agar medium. Squares cut from agar plates were exposed to osmic acid vapour for 1 $1 \frac{1}{2}-\mathbf{2}$ min. and inverted on cover-glasses; then lifted off, leaving an imprint of fixed bacteria on the glass. When the growth to be fixed was heavy the agar squares were pushed diagonally across the cover-slip, producing a rapidly drying smear. Fixed preparations were stored in $70 \%$ ethanol. Comparison of fixed, unstained bacteria with living ones has shown that this method gives life-like fixation, and that the brief drying after fixation has no damaging effect on the cells.

Staining of cell walls. (1) Dried films of fixed bacteria were mordanted for $30 \mathrm{~min}$. in $5 \%$ tannic acid and then stained for $1 \mathrm{~min}$. with $0.02 \%$ crystal violet in water. In ordinary bacteria the cell wall and the cell membrane (i.e. the outer layer of the protoplast) are readily and differentially stained by this method (Robinow, 1945), but $C$. latum stains rather slowly. Clear-cut staining of the cross-walls in the interior of the large bacteria was sometimes only complete $\mathbf{1 2 - 2 4} \mathrm{hr}$. after the stained films had been mounted in water.

(2) Staining of the cell walls and cell membranes was achieved more quickly by flooding fixed and dried smears for 3-5 min. with Morton's flagella stain (tannic acid potassium alum night blue solution; Smith, 1905). In combination with this stain an orange light-filter was used.

Staining of cell contents. Fixed preparations were stained for $\frac{1}{2} \mathrm{hr}$. with Giemsa solution ( $1 \mathrm{drop} / \mathrm{ml}$. of water) and differentiated under the microscope in water at approx. pH $5 \cdot 5$ (prepared by adding 2 or 3 loops of glacial acetic acid to a Petri dish of distilled water).

Staining of chromatinic structures. These were differentiated from the cytoplasm by treating fixed preparations for $7 \mathrm{~min}$. with $\mathrm{N}-\mathrm{HCl}$ at $56-60^{\circ}$, rinsing in tap water and distilled water and staining with Giemsa solution (Piekarski, 1937; Robinow, 1944, 1945; Vendrely \& Lipardy, 1946; Vendrely, 1946), and differentiating with acetic acid water as above. The Feulgen reaction for chromatinic structures was carried out in the usual way. Following hydrolysis with $\mathrm{N}-\mathrm{HCl}$ for $7 \mathrm{~min}$. at exactly $60^{\circ}$, the preparations were left for $5 \mathrm{hr}$. in Schiff's reagent, rinsed in three changes of $\mathrm{SO}_{2}$ water followed by $1 \mathrm{hr}$. in running tap water, counterstained with light green and mounted in DPX (British Drug Houses Ltd.).

\section{Cellular structure of Caryophanon latum}

Our idea of the cellular organization of C. latum is represented diagrammatically in Text-fig. 1. The systems of primary and secondary cross-walls, shown in the diagrams, are visible in the living organisms and inside the transparent shells of lysed filaments from old cultures (Pl. 3, fig. 10); they are also easily demonstrated in fixed specimens by both direct and indirect means. Indirect methods give the more impressive results and will be described first. 
Basic dyes are much more firmly held by the protoplasts of C. latum than by its cell walls, and if staining in Giemsa solution or methylene blue is followed by brief differentiation in weakly acid water, the bacterial filaments are transformed into seemingly disjointed columns of deeply stained discoid or short cylindrical sections consisting of the cytoplasm and the nuclear structures, separated and bounded externally by colourless, faintly refractive membranes, i.e. outer cell wall and cross-walls. Secondary cross-walls projecting centripetally into the cytoplasm - in the manner familiar from studies of filamentous Cyanophyceae and certain bacteria (Robinow, 1945)-are demonstrated particularly clearly in this way (Pl. 2, fig. 5).

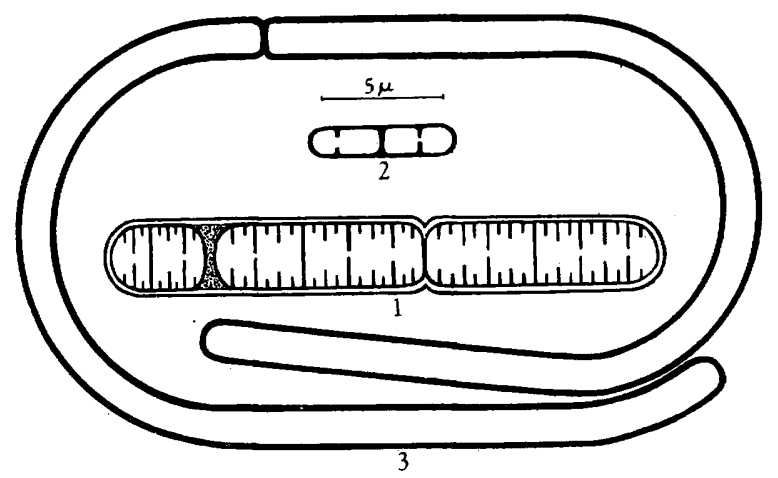

Text-fig. 1. Diagram to scale, illustrating the structural differences between Caryophanon latum (1), an ordinary bacterium (B. cereus) (2), and Lineola longa (3). Only the cell walls are shown; the cell contents and flagella have been omitted. The stippling of the biconcave section in Caryophanon latum indicates disintegration of the contents of one component cell.

The appearance is reversed with Morton's stain or tannic acid-crystal violet. These stains leave the cell contents almost colourless, while outer cell wall and transverse partitions in various stages of development are very distinctly stained and faithfully reflect the pattern of transverse lines which is so characteristic a feature of the living organism (Pl. 3, figs. 8, 9).

The refractive biconcave cells already referred to, which occur here and there among the normal discoid cells of living filaments, appear darker than normal cells in stained preparations (Pl. 3, fig. 8). They are cell chambers containing the remnants of disintegrated protoplasts.

Some of the cross-walls, usually the median ones, are continuous, but most have the shape of annular diaphragms, some with wide, others with narrow central apertures (Pl. 3, fig. 10). It would be incorrect, however, to assume on account of the apertures in the cross-walls that $C$. latum has a coenocytic structure. There is evidence that sister protoplasts are separated, presumably by the formation of cell membranes, before the closure of the central aperture in the cross-wall. This may be inferred from the readiness with which the bacterial filaments break up into their component protoplasts when placed in strong solutions of potassium nitrate or sodium chloride (Pl. 1, fig. 4), and in the variety of division stages to be found among the cells of the same filament. 
The sectional construction of the bacteria is emphasized by the fact that disintegration of occasional protoplasts in the same filament, already referred to as giving rise to refractive, biconcave cells, is not accompanied by the dissolution of the rest of the filament. The number of concave cells per filament varies greatly, and the distribution of concave cells in the filaments is entirely at random.

This morphological picture is further complicated by the beginnings of tertiary cell walls which can often be detected arising from the outer cell wall of growing filaments and projecting into the cytoplasm in the narrow spaces between primary and secondary cross-walls, (Text-fig. 1). The simultaneous presence of cross-walls in three different stages of development-continuous, those with a central aperture and mere ridges on the inner surface of the outer cell-wall-gives a very close and remarkably regular striation which is best seen after fixation or in strong salt solutions. This pattern of transverse lines is shown in Pl. 2, figs. 6 and $7 a$ and Pl. 3, fig. 8.

Peshkoff's serial photomicrographs of growing rod forms of $C$. latum provide additional evidence that their component cells (or nuclei in the author's interpretation) divide independently. Provided the conditions of cultivation are optimal, however, the length of the rods is kept within narrow limits by the correlation of the rates of growth of the rod forms with their transverse fission. Fission takes place by gradual constriction in or near the middle region, in the plane of one of the preformed cross-walls. Secondary constrictions are often apparent in the middle region of daughter bacteria before the division of the parent organism is complete.

\section{The chromatinic structures of Caryophanon latum}

The interior of the bacterial cells is occupied by large chromatinic structures which are difficult to demonstrate by ordinary staining methods because they are largely obscured by the basophilic cytoplasm. These configurations are more clearly differentiated from the cytoplasm if staining is preceded by hydrolysis of the fixed organisms with $\mathrm{N}-\mathrm{HCl}$, a method which has already proved very useful in studies of the cytology of spores and vegetative cells of ordinary bacteria (Piekarski, 1937; v. Plotho, 1940; Robinow, 1944, 1945; Klieneberger-Nobel, 1945). Interpretation of the chromatinic structures is difficult, chiefly because in the narrow compartments into which the cell chambers are divided by developing secondary cross-walls, the chromatinic structures can only be viewed in profile. A better view is afforded by the hemispherical cells at the tips of the filaments, by the single spherical cells and the short two- or three-cell rods which abound in old cultures, and by the component cells of fixed and stained filaments disrupted by pressure. Comparatively favourable material for the study of the chromatinic structures is also provided by organisms fixed 1 or $2 \mathrm{hr}$. after transfer to fresh nutrient medium, in which more space is available for the chromatinic configurations than in the cells of organisms from older cultures.

Characteristic differences are found between the chromatinic structures in 
organisms fixed during the lag phase of multiplication following transfer, in cells from young growing colonies, and in cells from old cultures. During the resting stage the chromatinic matter is often arranged as a continuous ring, or in horseshoe fashion, around a disk of non-chromatinic material (Pl. 4, figs. 11-13) resembling, on a larger scale, the structure of the nuclei of resting bacterial spores. In growing cells the chromatinic structures appear to be composite and are more difficult to analyse (Pl. 4, fig. 14). Certain configurations, which were frequently seen, suggest that each group may be composed of several small, more or less rod-shaped bodies which multiply by longitudinal division (Pl. 4, fig. 15). Dividing chromatinic structures are numerous in the bacterial filaments from young cultures, but the detail of the process of multiplication is far less clear than it is in ordinary bacteria like Bacterium coli and Bacillus cereus. Division seems to coincide with, not to precede, the inward progress of developing cross-walls.

The chromatinic structures give a well defined, if not very intense, positive Feulgen reaction. As in ordinary bacteria, the chromatinic structures in Caryophanon latum are not only more intensely stained by Giemsa solution (after hydrolysis), but are also slightly larger than in Feulgen preparations. First emphasized by Piekarski (1937), this effect, has more recently also been noted by Wendler-Deane (1945) in Plasmodium vivax and P. knowlesi.

The presence of these structures in every cell at all stages of the growth cycle, their size and central position, as well as the fact that they are most conspicuous at times of most intense growth activities, indicate that they are important cell organelles. More specifically, the staining properties and the regular multiplication of the chromatinic structures suggest that they represent a true, though perhaps a primitive, nuclear apparatus.

Our photograph (Pl. 1, fig. 3) shows that the component protoplasts of living, unstained rods of $C$. latum appear brighter than the narrow partitions which separate them. This difference is accentuated by Peshkoff's 'doublenegative' method of photography (1940). Photographs of living 'Achromobacter Epsteinii' (Peshkoff, 1938) and of living Proteus vulgaris (which we have been able to examine through Dr Peshkoff's courtesy), in which bright configurations corresponding to the nuclear structures are clearly visible in the living bacteria, have induced Peshkoff to interpret the bright sections of the $C$. latum filaments in the same way. We are forced to disagree with this view, since the study of stained preparations has shown us that the bright sections in photographs of the living rods, Peshkoff's as well as ours, represent whole protoplasts, i.e. not only nuclei but also the cytoplasm which contains them.

In addition to the nuclear structures the cytoplasm usually contains varying numbers of small metachromatic granules which are conspicuous in fixed and stained cells not pretreated with $\mathrm{HCl}$, but absent from the cytoplasm of hydrolysed bacteria.

A beaded condition of the cytoplasm was often encountered in the ridges flanking inwardly progressing cross-walls. It may have been this cytoplasmic granulation that has led Peshkoff (1946) to assume the existence of numerous 
ring chromosomes with distinct 'chromomeres' in the cells of Caryophanon. The true relationship of sets of the beaded ridges arising from the surface of the cytoplasm to the nuclear structures in the interior, is evident from a comparison of figs. $7 a$ and $b$ of Pl. 2.

\section{The taxonomic position of Caryophanon}

The general appearance of the organism and the character of the nuclear structures suggested to Peshkoff (1940) the existence of a 'direct relationship to the blue-green algae'. We do not agree with this hypothesis, but it must be admitted that many features of Caryophanon-the filamentous growth habit, the discoid cells, the occasional occurrence among them of empty, concave 'necridia' and the formation of hormogonia in the fragmentation of long filaments in old cultures-are reminiscent of certain Cyanophyceae, e.g. species of Oscillatoria. This similarity is, however, insufficient to establish a true taxonomic relationship.

Much more convincing, in our opinion, is the evidence relating Caryophanon to the great group of true bacteria. The features of Caryophanon which suggest this designation are (1) motility due to the presence of typical, peritrichate flagella; (2) regular binary fission of the composite rods; (3) the absence of a distinctive slime layer. The fact remains, nevertheless, that in Caryophanon one encounters structural features previously unknown in bacteria. To mention but one and perhaps the most obvious of these, the individual, which behaves in a manner analogous to a paucicellular rod form of, say Bact. coli, is really a many-celled filament (trichome).

Rod forms composed of more than one cell, it is true, are common in young cultures of many ordinary bacteria, and filamentous forms are well known in many species, but the former divide at the two- or four-cell stage and the latter do not behave as units of multiplication and are but transient stages in the growth cycle, followed by fragmentation or spore formation.

C. latum has much in common with some of the relatively large filamentous micro-organisms which have repeatedly been described as occurring in the intestines of various herbivorous mammals and which have in the past commonly been regarded as colourless blue-green algae. One of these, Oscillospira guilliermondi Chatton \& Perard (Oscillaria caviae Simons), an inhabitant of the intestines of the guinea-pig, we have begun to investigate. Though exceeding $C$. latum in size, $O$. guilliermondi resembles that organism very closely in general appearance and construction, is motile by means of peritrichate flagella (Robinow, unpublished), and has the same kind of discoid cells and chromatinic structures. Pure culture studies on other members of this group are needed before the classification of these bacteria can be profitably undertaken.

\section{LINEOLA LONGA (nomen provisorium)}

In the multitude of micro-organisms seen in cow dung infusions another filamentous bacterium attracted our attention by its motility, combined with very great length and more than ordinary width. In its morphology and 
cytology it is so different from ordinary bacteria and also from C. latum that we propose to compare it with the latter. It will be described more fully in a separate paper and is here referred to under the provisional name Lineola longa.

The filaments formed by this bacterium are not as wide as those of C. latum but usually much longer. They are sufficiently tough and flexible to withstand much twisting and bending. Even the very long filaments are motile by means of peritrichous flagella. Like C. latum, L. longa does not actively alter its shape, and the seemingly writhing, snake-like character of its ponderous swimming movements is due to curvatures of the long filaments and to the rotation on their axis.

The filament diameter, $1 \cdot 5-2 \mu$., does not exceed that of, for example, the rod forms in young cultures of Bacillus megatherium; it is the length that is extraordinary. Filaments 30-50 $\mu$. long are common in agar cultures, and much greater lengths, up to $200 \mu$, are attained in liquid media. Cross-walls observable after tannic acid + crystal violet staining, occur at irregular intervals and are few and far between (PI. 5, fig. 16). Filaments more than $50 \mu$. long consist of several sections; in shorter forms it is rare to find more than one cross-wall per filament. Staining with Giemsa solution reveals the absence of further subdivisions between the cross-walls and shows that filaments are built up of a small number of cells.

L. longa contains large numbers of small, rod- or dumb-bell-shaped Feulgenpositive bodies, similar in arrangement and appearance to those which Klieneberger-Nobel (1945) demonstrated in Clostridium oedematiens var. gigas. Attempts to stain these bodies by the HCl-Giemsa method have not given convincing results, and detailed observations on these structures have not yet been possible. Multiplication is by transverse fission in the plane of a preformed cross-wall. Often, but by no means always, fission divides a filament into halves.

\section{DISCUSSION}

C. latum and $L$. longa have certain general characters in common. They share a common habitat, they are both uncommonly large, peritrichously flagellated, Gram-negative and non-sporing, and they are difficult to define taxonomically. But they differ conspicuously in their construction. C. latum is closely subdivided into discoid cells and bears a superficial resemblance to filamentous Cyanophyceae. L. longa lacks subdivision into mononucleate compartments and, apart from the length of its component cells, is built like an ordinary bacterium. It differs from the filamentous forms of the latter and, indeed, from Caryophanon in that the filamentous growth habit is its only form of existence, there being no stage in its growth cycle at which fragmentation into small units takes place.

We have pleasure in thanking Dr R. Y. Stanier for helpful suggestions and constructive criticism and Dr F. W. G. Lund for his assistance in searching for Caryophanon in the Lake District. 


\section{REFERENCES}

Klieneberger, E. \& Smiles, J. (1942). Some new observations on the developmental cycle of the organism of bovine pleuropneumonia and related microbes. J. Hyg., Camb., 42, 110.

KLIENeberger-Nobel, E. (1945). Changes in the nuclear structure of bacteria, particularly during spore formation. J. Hyg., Camb., 44, 99.

Migula, W. (1897). System der Bakterien, 1. Jena.

Peshroff, M. A. (1938). Parallel study of stained and live nuclei of Achromobacter Epsteinii. Biol. J. (Russ.), 7, 1035.

Peshroff, M. A. (1940). Phylogenesis of new microbes, Caryophanon latum and Caryophanon tenue, organisms which are intermediate between blue-green algae and the bacteria. (Detailed summary in English.) J. gen. Biol. (Russ.), 1, 598.

Peshkoff, M. A. (1946). Fine structure and mechanism of division of the 'nuclei' of the bacterium Caryophanon latum. Nature, Lond., 157, 137.

Piekarski, G. (1937). Cytologische Untersuchungen an Paratyphus und Colibakterien. Arch. Mikrobiol. 8, 428.

Plotho, O. v. (1940). Die chromatische Substanz bei Actinomyceten. Arch. Mikrobiol. 11, 285.

Pringsheim, E. G. (1937). Beiträge zur Physiologie saprophytischer Algen und Flagellaten. I. Planta, 26, 631.

Pringshein, E. G. (1946). Pure Cultures of Algae. Cambridge University Press.

RoBinow, C. F. (1944). Cytological observations on Bact. coli, etc. J. Hyg., Camb., 43, 413.

Rosinow, C. F. (1945). Addendum to The Bacterial Cell, by René J. Dubos. Cambridge, Mass.: Harvard University Press.

Sмгтн, E. F. (1905). Bacteria in Relation to Plant Diseases, 1, 220. Washington D.C., Carnegie Institute of Washington.

Vendrely, R. (1946). Les deux acides nucléiques bactériens et leur signification. Congrès de Chimie Biologique de Liège (Octobre 1946).

VENdRely, R. \& Lipardy, J. (1946). Acides nucléiques et noyaux bactériens. C.R. Acad. Sci., Paris, 223, 342.

Wendler-Deane, H. (1945). Studies on malarial parasites. II. The staining of two primate parasites by the Feulgen technique. J. cell. comp. Physiol. 26, 139.

\section{EXPLANATION OF PLATES}

Unless otherwise stated osmic acid vapour is the fixative used for stained preparations. All stained preparations were photographed mounted in water.

\section{Plate 1}

Fig. 1. Caryophanon latum in cow dung after 4 days at room temperature. Nigrosin smear. $\times 650$.

Fig. 2. Small colony of the smooth type on beef-extract + yeast-extract acetate agar $(10: 1)$ after $18 \mathrm{hr}$. at $26^{\circ} . \times 154$.

Fig. 3. Edge of a living colony of Caryophanon latum incubated for $24 \mathrm{hr}$. at $26^{\circ}$. The filaments are closely subdivided by numerous cross-walls. The two refractile biconcave segments in the central filament are disintegrated cells. $\times 1700$.

Fig. 4. Living, unstained filaments of Caryophanon latum plasmolysed in saturated solution of sodium chloride. $\times 2350$. 
Plate 2

Fig. 5. Cellular structure of Caryophanon latum from a $24 \mathrm{hr}$. culture. Only the cell contents (cytoplasm plus nuclei) are stained. Outer cell wall and cross-walls are not stained, and the bacteria consequently appear as columns of disjointed, disk-shaped protoplasts. The peripheral notches are optical sections of grooves in the cytoplasm caused by developing secondary and tertiary cross-walls. Osmic acid, Giemsa. $\times 2700$.

Fig. 6. Different stages of transverse fission of typical C. latum individuals resembling the growth habit of ordinary bacteria. Differences in the appearance of the filaments are due to their lying at different levels of focus. Thus, surface detail, i.e. a closely spaced transverse striation, is in sharp focus in the bacterium indicated by the arrow, whereas the unstained nuclear structures in the interior are in focus in others. Tannic acid, crystal violet. $\times \mathbf{2 7 0 0}$.

Figs. $7 a, b$. Two photographs of the same group of filaments from a young culture. $(a)$ Close striation of the cytoplasm caused by incipient and more or less fully formed cross-walls. The cytoplasm is granular. (b) The nuclear structures in the interior after treatment with HCl. Giemsa preparations. $\times 2700$.

Plate 3

The magnification of the photographs on this plate is indicated by the scale underneath fig. 8 .

Fig. 8. Formation of 'hormogonia' by the fragmentation of long filaments in a culture 4 days old. Note the darkly stained biconcave disintegrated cell in the right half of the upper of the two long filaments. 'The pattern of primary and secondary cross-walls is very clear and emphasizes the life-like fixation obtained with osmic vapour. Mordanted with $5 \%$ tannic acid, lightly stained with $0.02 \%$ crystal violet.

Figs. 9a, $b$. Two photographs of a group of filaments from a $4 \mathrm{hr}$. old culture of Caryophanon latum; stained first with night-blue-tannic acid, to show the cell boundaries $(a)$ and afterwards treated with $\mathrm{HCl}$ and stained with Giemsa solution to show the cytoplasm and the chromatinic structures of the component cells of the same group of filaments $(b)$.

Fig. 10. Empty transparent shells of a chain of $C$. latum individuals from a 6-week-old agar culture. The cell contents have lysed, but the outer cell wall and the cross-walls remain. Most of the cross-walls are not yet fully formed and are annular diaphragms.

\section{Plate 4}

The magnification of the photographs on this plate is indicated by the scale alongside fig. 14 .

Figs. 11-13. Flat nuclei with peripheral concentrations of chromatin in resting forms of Caryophanon latum from 4-5-day-old cultures. A single cell, spherical during life, is seen in the upper half of fig. 12. In the short cells of the composite individuals in figs. 11 and 13 most of the nuclei are seen sideways; a fuller view of them is obtained in some of the more or less hemispherical end-cells.

Fig. 14. Compact, polygonal, chromatinic structures in growing rod forms of Caryophanon latum, fixed $1 \frac{1}{2} \mathrm{hr}$. after transfer from an old culture to fresh nutrient medium.

Fig. 15. Chromatinic structures in growing filaments fixed $\mathbf{5} \mathbf{~ h r}$. after transfer from an old culture to fresh nutrient medium. Most of the chromatinic structures in the filament to which the arrow is pointing seem composed of groups of small dumb-bell-shaped rodlets.

\section{Plate 5}

Fig. 16. Lineola longa. Osmic acid, tannic acid, crystal violet, smear preparation. $\times 3000$. 
Journal of General Microbiology, Vol. 1, No. 3

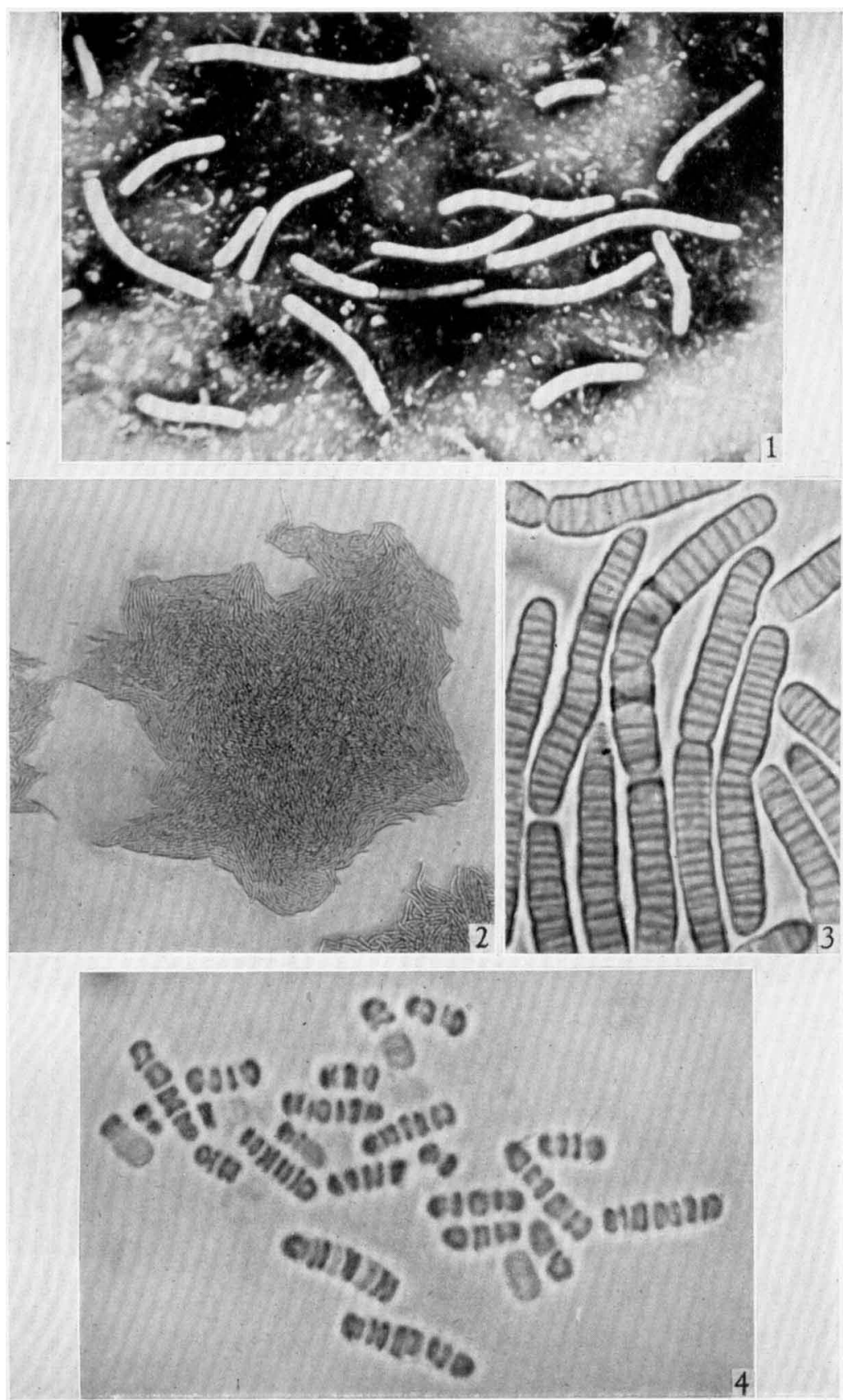

Figs. 1-4.

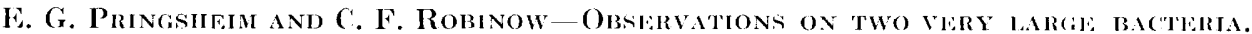
PIATE: 1 
Journal of General Microbiology, Vol. 1, No. 3

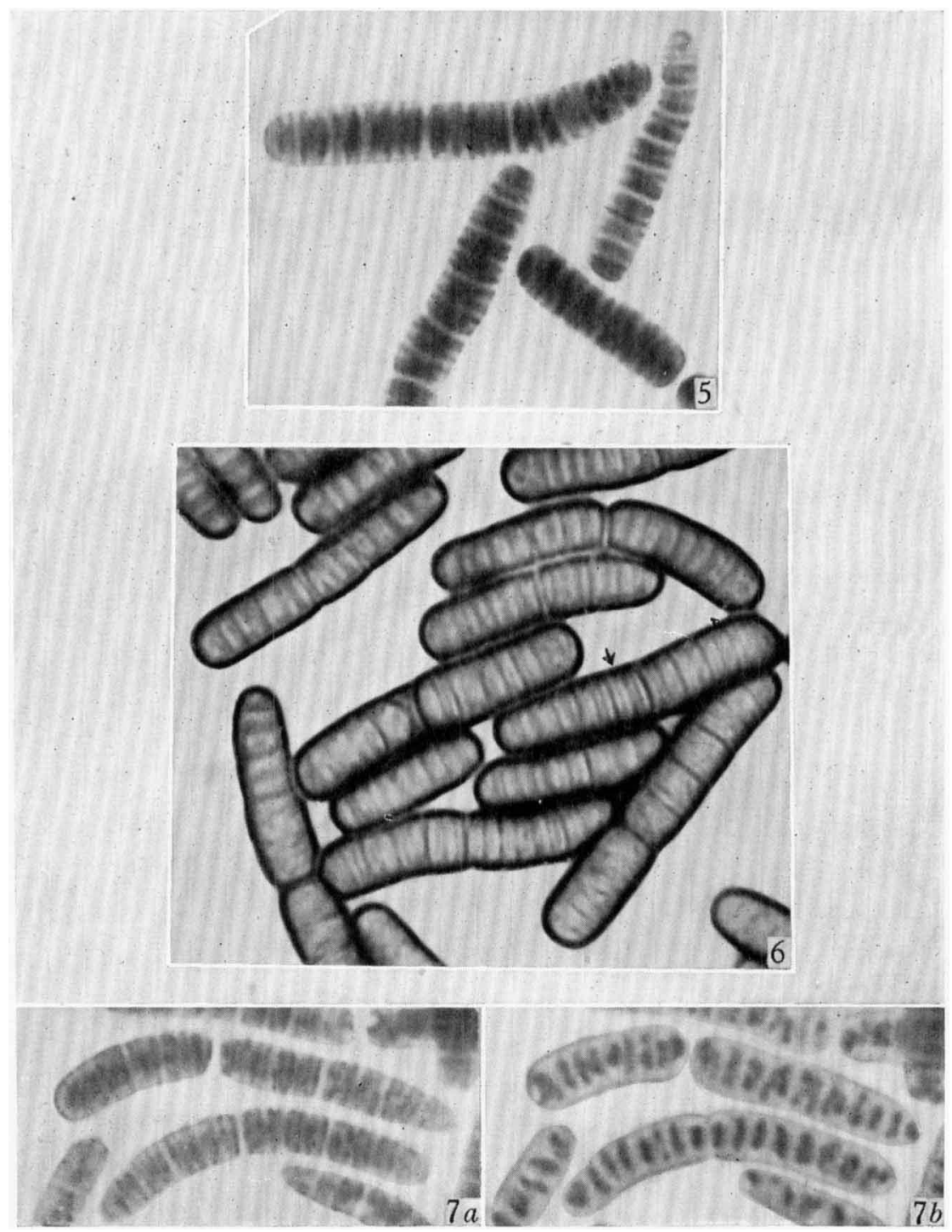

Figs. 5-7 $b$

E. G. Pringsheim and C. F. Robinow--Observations on two very large bacteria. Plate 2 
Journal of General Microbiology, Vol. 1. No. 3

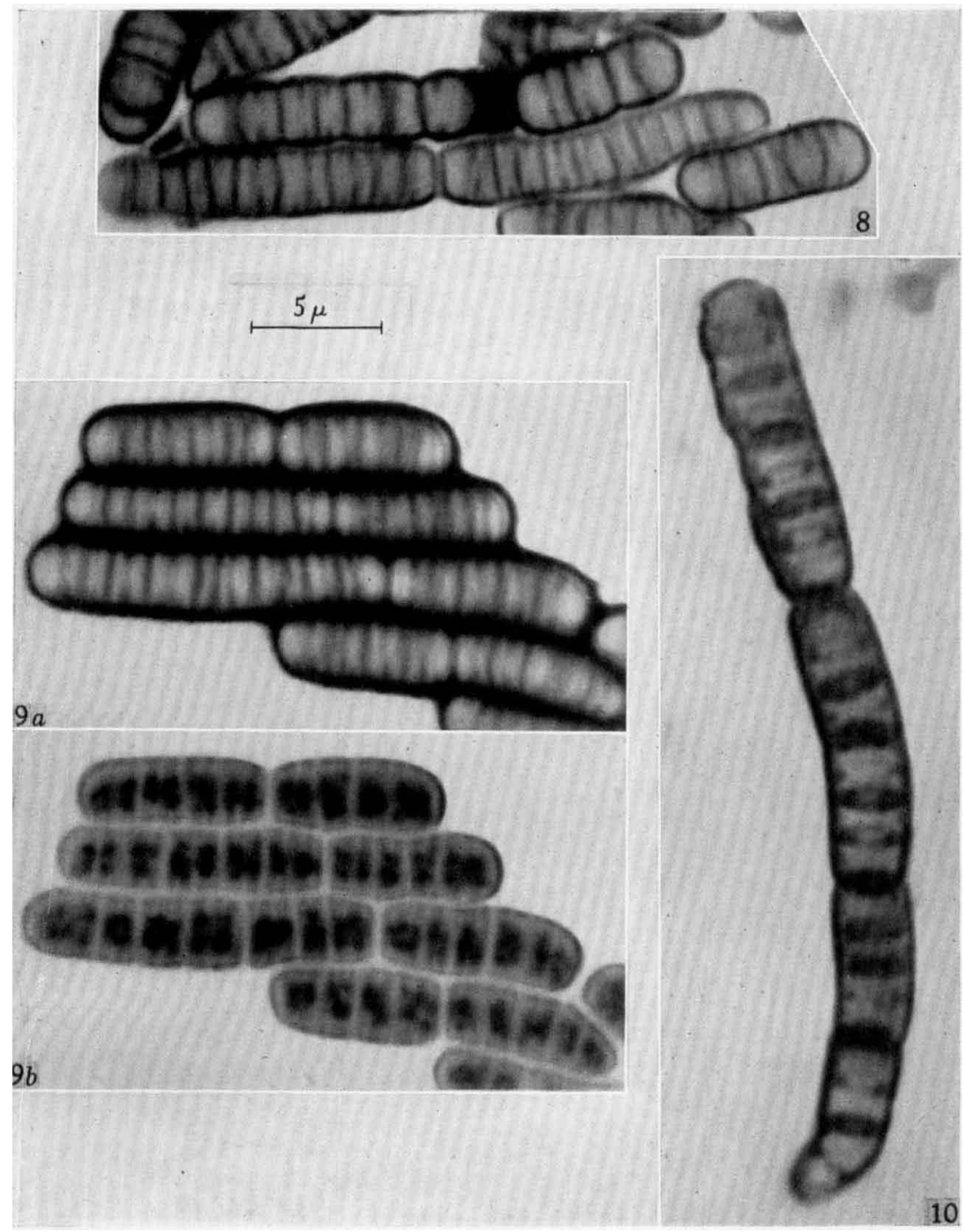

Figs. 8-10

E. G. Pringsheim and C. F. Robinow-Observations on two very large bacteria. Plate 3 
Journal of General Microbiology, Vol. 1, No. 3
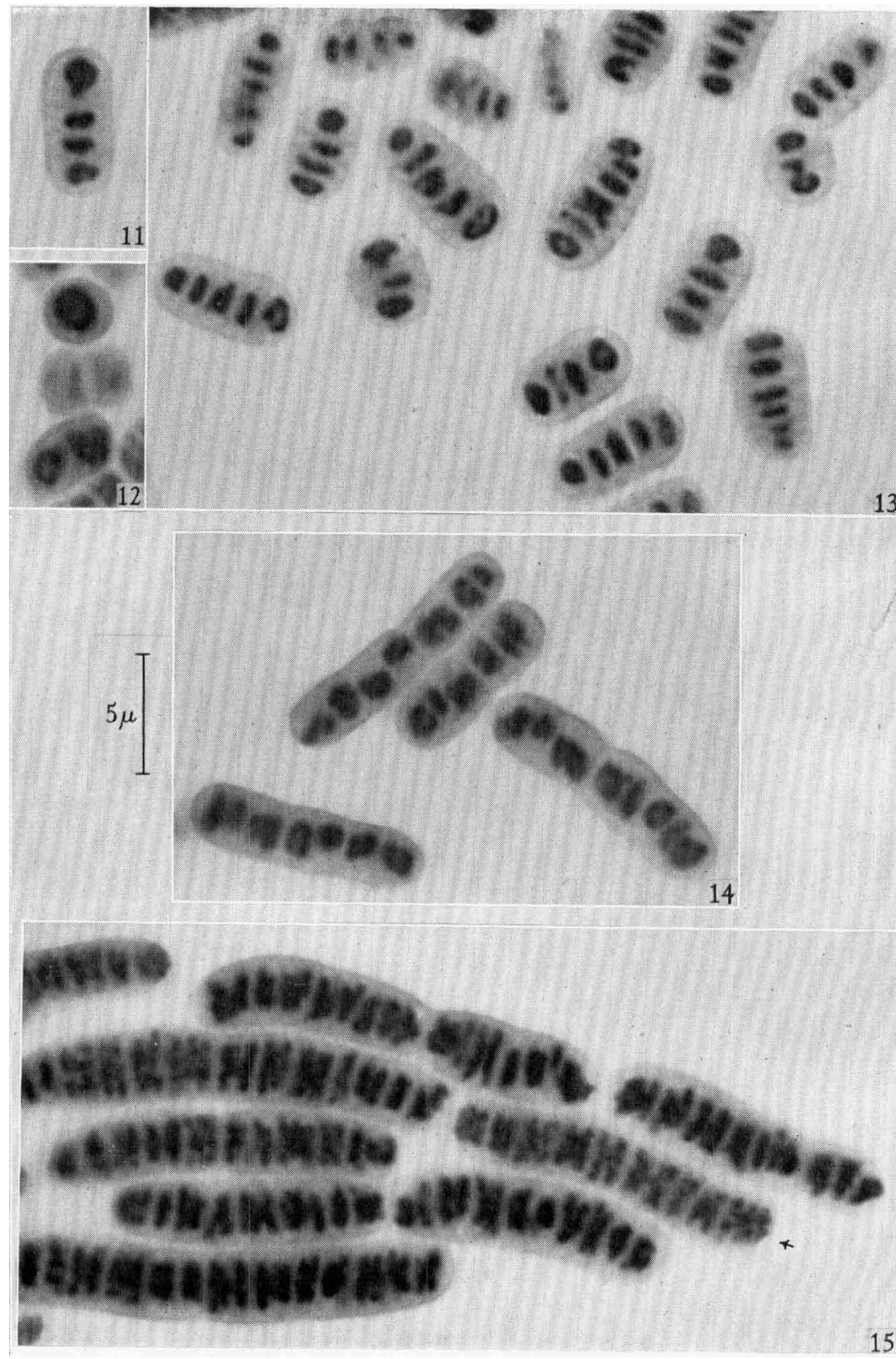

Figs. 11-15

E. G. Pringsimim and C. F. Robinow-Obsemvations on two very iarge bacteira. Piate 4 
Journal of General Microbiology, Vol. 1, No. 3

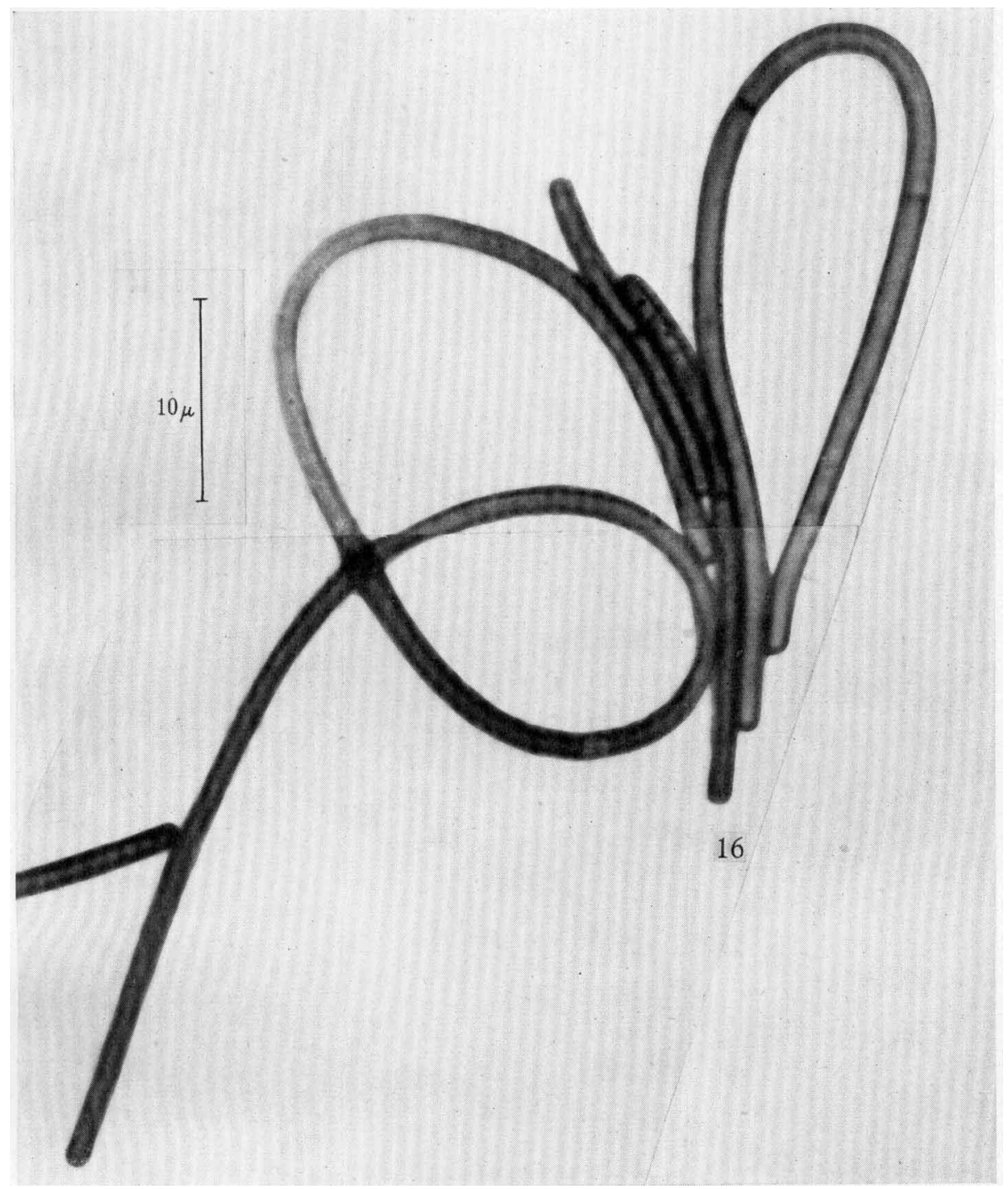

Fig. 16

k. G. Pringsheim and C. F. Robinow Observations on two very large bacteria. Plate 5 